\title{
Primary pulmonary sarcoma - long-term treatment outcomes and prognostic factors
}

\author{
Janusz Gołota ${ }^{1}$, Karolina Osowiecka², Tadeusz Orłowski ${ }^{3}$ \\ ${ }^{1}$ Thoracic Surgery Clinical Ward, Municipal Polyclinical Hospital, Olsztyn, Poland \\ ${ }^{2}$ Department of Surgery, Institute of Lung Diseases and Tuberculosis, Warsaw, Poland \\ ${ }^{3}$ Department of Public Health, University of Warmia and Mazury, Olsztyn, Poland
}

Kardiochirurgia i Torakochirurgia Polska 2018; 15 (3): 162-169

\begin{abstract}
Introduction: Primary pulmonary sarcoma (PPS) is a rare type of non-epithelial malignant tumour of the lungs. Lung sarcomas are usually of metastatic character, originating from the primary tumour located in another organ. Pathomorphological diagnosis is difficult and therefore definitive diagnosis is usually determined after surgical treatment. Five-year survival of radical operated patients is $42-69 \%$.

Aim: To evaluate prognostic factors in PPS.

Material and methods: Twenty-two patients who underwent surgical treatment between 1994 and 2009 were analysed.

Results: Ten types of sarcomas were identified. All 22 analysed patients underwent operations and in 14 (63.6\%) cases it was $\mathrm{R}_{0}$ resection (pneumonectomies, lobectomies, non-anatomical resections). In 8 out of 22 patients a locally advanced form was identified. Median overall survival (OS) in the group of all patients was 22 months, 5- and 10-year OS was $27 \%$ and $18 \%$ respectively, whereas in patients who underwent non-anatomical lung resections it was $80 \%$ and $60 \%$ respectively with median OS of 213 months. Overall survival was dependent on gender, completeness of treatment and size of tumour. Haemoptysis was a poor prognostic factor. Primitive neuroectodermal tumour was a type of sarcoma with a negative effect on progression-free survival. No impact of age, type of sarcoma, degree of histological malignancy, stage or adjuvant treatment on OS was noted.

Conclusions: Primary radical surgical resection prolongs patient survival. Patients with tumours larger than $5 \mathrm{~cm}$ and men have worse prognoses. Future studies conducted on larger groups of patients diagnosed with PPS are necessary.
\end{abstract}

Key words: primary pulmonary sarcoma, surgery, overall survival, prognostic factors.

\section{Streszczenia}

Wstęp: Pierwotne mięsaki płuca (PPS) to grupa rzadko występujących nienabłonkowych nowotworów złośliwych płuc. Mięsaki w płucach mają najczęściej charakter przerzutów z ogniska pierwotnego umiejscowionego w innym narządzie. Ocena patomorfologiczna jest trudna, a chorobę rozpoznaje się przeważnie po operacji. Pięcioletnie przeżycie pacjentów poddanych radykalnemu leczeniu operacyjnemu wynosi 42-69\%. Cel: Określenie czynników prognostycznych PPS.

Materiał i metody: Analizie poddano 22 pacjentów leczonych chirurgicznie w Klinice Chirurgii Instytutu Gruźlicy i Chorób Płuc w Warszawie od 1994 do 2009 r.

Wyniki: Rozpoznano 10 typów mięsaka. Leczeniu chirurgicznemu poddano wszystkich 22 pacjentów. Operacje $R_{0}$ wykonano u 14 (63,6\%) pacjentów. Resekcje obejmowały: pneumonektomie, lobektomie i resekcje nieanatomiczne. U 8 spośród 22 chorych (36\%) stwierdzono postać zaawansowaną miejscowo. Mediana całkowitego przeżycia (OS) dla wszystkich pacjentów wyniosła 22 miesiące, natomiast 5- i 10-letnie OS - odpowiednio $27 \%$ i $18 \%$, a u pacjentów, u których wykonano resekcje nieanatomiczne - odpowiednio $80 \%$ i $60 \%$ przy medianie 213 miesięcy. Całkowite przeżycie było zależne od płci, doszczętności leczenia i wielkości guza. Źle rokującym objawem było krwioplucie. Typ mięsaka PNET źle wpływał na czas wolny od wznowy choroby (PFS). Nie stwierdzono, aby wiek, typ mięsaka, stopień złośliwości histologicznej, stopień zaawansowania i leczenie uzupełniające korelowały z przeżyciem całkowitym.

Wnioski: Pierwotnie radykalne leczenie operacyjne wpływa na wydłużenie przeżycia. Gorsze rokowanie mają pacjenci z guzami większymi niż $5 \mathrm{~cm}$, a także mężczyzni. Przyszłe badania powinny być prowadzone w większych grupach pacjentów $z$ rozpoznanym PPS.

Słowa kluczowe: pierwotny mięsak płuc, chirurgia, całkowite przeżycie, czynniki prognostyczne.

Address for correspondence: Janusz Gołota, Thoracic Surgery Clinical Ward, Municipal Polyclinical Hospital, 44 Niepodległości St, 10-044 Olsztyn, Poland, phone: +48 510087 490, +48 89532 63 57, e-mail: januszgolota@vp.pl

Received: 10.07.2018, accepted: 18.08.2018. 


\section{Introduction}

Primary pulmonary sarcomas (PPS) are a diverse group of rarely occurring non-epithelial malignant tumours that originate from mesenchymal tissue of the lung. The PPS can originate from mesenchymal elements of bronchial wall, vessels or pulmonary stroma. They usually infiltrate lung parenchyma and create clearly demarcated, but not encapsulated tumours that can also spread inside bronchi but rarely infiltrate bronchial epithelium [1-4]. Metastases significantly outnumber primary tumours, with the ratio $3000: 1[3]$. Apart from the difficulty in distinguishing primary and secondary tumours, lung sarcomas must also be distinguished from numerous sarcoma-like primary tumours of the lung [2]. Since the introduction of immunohistochemical and molecular diagnosis, a significant improvement in description and classification of sarcomas has been achieved. Nonetheless, sarcomas still remain a diagnostic dilemma. PPS comprise only $0.013-1.1 \%$ of all malignant lung tumours [5-7]. The majority of available literature concerning PPS is limited to descriptions of either single or very small series of sarcoma cases. The largest of them were described by Mac Cormac and Martini during 64 years (42 patients) and by Regnard -24 cases during 25 years [8-11]. The majority of reports describing single cases of PPS concern synovial sarcoma (sarcoma synoviale - SaSy). However, when the authors analyse larger series of cases, the most common PPS are malignant fibrous histiocytoma (MFH), fibroblastic sarcoma and leiomyosarcoma [7-12].

Although PPS are often asymptomatic, as the tumour grows, symptoms related to infiltration of the thoracic wall or pressure exerted on the oesophagus, blood vessels or heart may start to appear. The low incidence and detection rate of this group of tumours contributed to the fact that commonly accepted prognostic factors were not identified until the beginning of the $21^{\text {st }}$ century.

\section{Aim}

Were determined long-term outcomes and prognostic factors for PPS.

\section{Material and methods \\ Material}

Twenty-two patients with PPS treated with surgery at the Surgical Clinic of the Institute of Tuberculosis and Lung Diseases in Warsaw (IGiChP) between January 1994 and December 2009 (16 years) were included in this study. All patients were included in the follow-up from the first surgery in January 1994 until 16 October 2016 in the Outpatient Clinic. In the event of recurrence patients were treated in the Maria Sklodowska-Curie Institute of Oncology in Warsaw (CO-I). The time of patients' observation was in the range 1-213 months (median time 23 months).

Patients with lesions in lungs which were metastases from other locations and patients with metastases in other organs identified at baseline were excluded from the analysis.

\section{Method}

Analysis included anamnesis, physical examination, results of laboratory tests, results of diagnostic imaging (Xray, ultrasonography (USG), computed tomography (CT), magnetic resonance imaging (MRI)), results of bronchofibroscopy, extent of surgical treatment, histopathological diagnosis, adjuvant treatment and clinical observation. The data were obtained from medical records and hospital databases.

\section{Statistical analysis}

Overall survival and progression-free survival were determined using the Kaplan-Meier method and differences between curves were assessed using the log-rank test in univariate analysis. Then the variables that were related to survival with a $p \leq 0.1$ were included in the multivariate analysis using the Cox proportional hazards model. The $\chi^{2}$ test was used to compare proportions in prognostic factors depending on sex. A $p<0.05$ was considered as statistically significant. Statistical analysis was carried out using Statistica (version 13) (StatSoft, Poland).

\section{Results}

From January 1994 to December 2009, in the Surgical Clinic of IGiChP, 22363 operations were carried out, 4343 of them because of lung tumour. The analysed group of 22 patients with PPS constituted $0.089 \%$ of the group of all operated patients and $0.506 \%$ of patients operated because of lung tumour. The analysed group included 10 (45\%) men and 12 (55\%) women. Patients were between 28 and 70 years old (median: 47.5 years).

In 18 patients ( $82 \%$ of analysed patients) the diagnostic symptoms haemoptysis and pain in the thorax were observed respectively in 9 (27\%) patients and 10 (45\%) patients. The time between symptoms and surgery was 0-14 months (median: 2.5 months).

Diagnostic imaging included X-ray, computed tomography (CT) of thorax, MRI, and USG of abdominal cavity. All patients underwent bronchofibroscopy. The histopathological confirmation of malignant tumour before the operation was obtained in $4(18 \%)$ patients. No cases of lung sarcoma were identified before surgical treatment - all patients were operated on because of suspicion or diagnosis of lung carcinoma. All patients had a single lesion in the lungs. Size of the tumour was between $1 \times 1 \mathrm{~cm}$ and $22 \times 12$ $\times 22 \mathrm{~cm}$ (median: $7.5 \mathrm{~cm}$ ). In $13(59 \%)$ patients the tumour was larger than $5 \mathrm{~cm}$ in the largest dimension, in 8 (36\%) patients it was smaller or equal to $5 \mathrm{~cm}$, and in one case information about size of the tumour could not be obtained.

All 22 patients underwent surgical treatment. $R_{0}$ surgeries were carried out in 14 (63.6\%) patients. Resections included: pneumonectomy in $4(18 \%)$ patients, lobectomy in $4(18 \%)$ patients - in one of these patients $(4.5 \%)$ expanded by resection of the atrium - and in $6(27 \%)$ patients wedge resection. Adjuvant therapy was carried out in 5 out of 14 patients who underwent radical treatment (36\%, 
$n=14)$ : in 2 patients from this group $(21 \%, n=14)$ standalone chemotherapy in schemes of VP + DDP + IFO (etoposide, cisplatin, ifosfamide) in the case of PNET and CTX + VCR + PFS (cyclophosphamide, vincristine, farmorubicin) in the case of MFH. In 3 patients $(36 \%, n=14)$ standalone radiotherapy was used.

In 8 out of 22 patients $(36 \%, n=22)$ a locally advanced form was primarily identified. In 2 of these patients (9\%) treatment was limited to insertion of a bronchial stent. Diagnostic thoracotomy was the only procedure in 6 out of 22 patients $(27 \%, n=22)$. Among patients with advanced tumours, palliative chemotherapy was used in 1 patient $(12.5 \%, n=8)$, palliative radiotherapy in 3 patients $(37.5 \%$, $n=8)$ and in the remaining 2 patients $(25 \%, n=8)$ combined therapy. Chemotherapy schemes involved adriamycin (ADM), ifosfamide (IFO), vincristine (VCR) and cyclophosphamide (CTX).

In 8 patients ( $36 \%$ of studied patients) disease progression occurred during observation. Local recurrence was identified in 5 patients (23\% of studied patients) and distant metastases were identified in 4 patients $(18 \%$ of studied patients). Distant metastases were located in bones (2 patients, $9 \%$ ), adrenal glands (1 patient, 4.5\%), and contralateral lung (1 patient, $4.5 \%$ ). In all 3 patients with PNET disease progression occurred, in 2 patients it took the form of distant metastases and in 1 patient local recurrence. In 1 patient with liposarcoma, both local recurrence and metastases to adrenal glands occurred. In 1 patient with angiosarcoma, during the observation period, ductal carcinoma of the breast was identified.

\section{Results of pathomorphological analysis}

Histological type of PPS was determined in accordance with the $3^{\text {rd }}$ edition of the WHO sarcoma classification. In the analysis 10 types of sarcomas were identified: MFH (4 patients; 18\%), leiomyosarcoma (3 patients; 13.6\%), haemangiopericytoma (3 patients; 13.6\%), neurosarcoma (3 patients; 13.6\%), PNET (3 patients; 13.6\%), synovial sarcoma (2 patients; $9 \%$ ), liposarcoma, angiosarcoma, chondrosarcoma, fibrosarcoma (1 patient each).

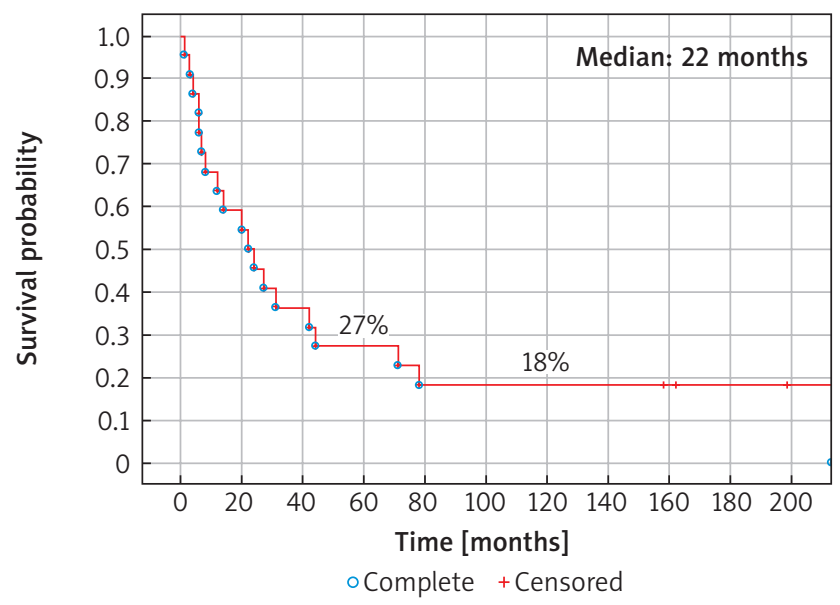

Fig. 1. Overall survival of all analysed patients
According to the $3^{\text {rd }}$ edition of the TNM soft tissue sarcoma (STS) classification developed by the Union for International Cancer Control (UICC) and the American Joint Committee on Cancer (AJCC) published by the WHO in 2002, stages of development of each type of sarcoma were determined as follows: stage IA $-4(18 \%)$ patients, stage IB - 2 (9\%) patients, stage IIA - 5 (23\%) patients, stage III $10(45 \%)$ patients. According to the $7^{\text {th }}$ edition of the TNM lung tumour classification published in 2009 by the UICC and AJCC, stages of development were determined as follows: T1NO - $3(13.6 \%)$ patients, T2NO - 6 (27\%) patients, T3NO - 9 (41\%) patients, T4NO - 4 (18\%) patients.

Microscopic examination of tissue material $(n=22)$ demonstrated 7 (32\%) tumours of low degree of histological malignancy (G1), 4 (18\%) tumours of moderate degree of malignancy (G2) and 11 (50\%) tumours with histogenesis implicating poor prognosis (G3).

\section{Analysis of distribution of various prognostic factors depending on sex}

Most of the men and women showed no symptoms such as cough, dyspnoea, or heart arrhythmia, whereas others experienced pain in the thorax. Unlike women, most of the men showed symptoms such as weakness and haemoptysis. Tumours larger than $5 \mathrm{~cm}$ were observed in most male and half of female patients. A tumour of stage T4 (lung tumour TNM) and grade G3 was frequently noted in men. Men were diagnosed with MFH and PNET more often. However, the differences between subgroups depending on gender, or other prognostic factors such as surgical radicalism, non-anatomical resections, age, palliative therapy, adjuvant therapy or time between symptoms' appearance and surgical treatment, were not statistically significant $(p>0.05)$.

\section{Overall survival (OS)}

Median OS in the group of all studied patients was 22 months, and 5- and 10 -year OS was $27 \%$ an $18 \%$ respectively (Fig. 1).

Women had better prognoses than men. Median time of OS in women was 42 months, whereas in men it was only 6 months ( $p=0.009$ ) (22 months in entire group). Fiveyear OS in women was $42 \%$ and in men $10 \%$ (27\% in entire group). No men survived 10 years, whereas in women 10-year OS was 33\%.

Median time of OS in patients with tumours smaller than or equal to $5 \mathrm{~cm}$ was 44 months, while in the case of tumours larger than $5 \mathrm{~cm}$ median time of OS was 14 months $(p=0.02)$. Five-year OS in patients with smaller tumours was $50 \%$ vs. $15 \%$ in patients with larger tumours; 10 -year OS was $38 \%$ vs. $8 \%$ respectively (Fig. 2).

Median OS in patients who underwent $\mathrm{R}_{0}$ resection was 27 months, while in the others it was 8 months $(p=0.047)$. Five- and 10 -year OS in patients who underwent radical treatment was $43 \%$ and $29 \%$ respectively. None of the patients who underwent R1-2 resection survived 5 years. Median OS in patients who were disqualified from radical treatment was 8 months (Fig. 3). 


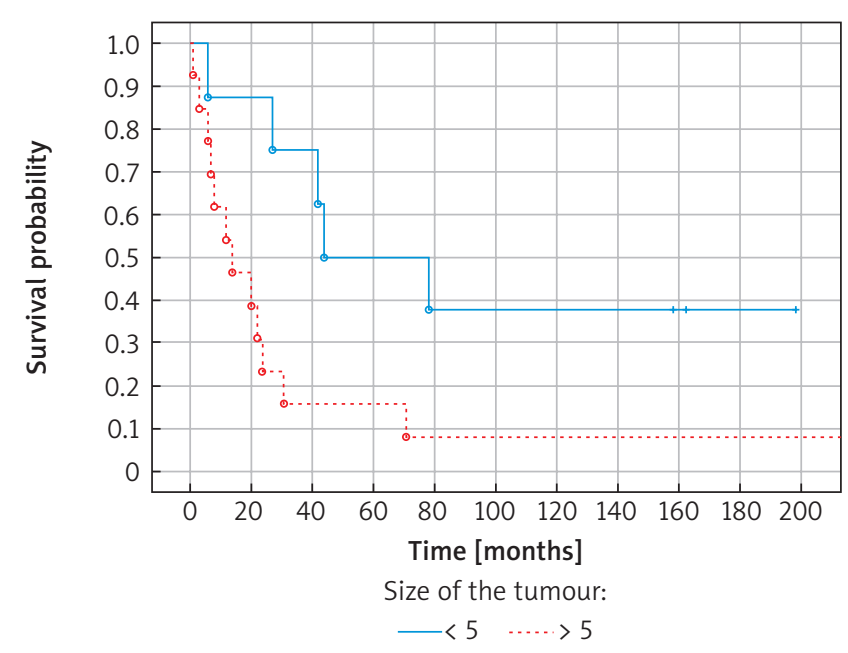

Fig. 2. Actuarial survival of all resected patients as a function of size of tumour (size is in $\mathrm{cm}$ )

While comparing types of surgery, it was found that OS in the case of non-anatomical resections was 213 months, while in all other cases it was only 14 months $(p=0.002)$. Five-year OS in patients who underwent non-anatomical resections was $80 \%$ in comparison to $12 \%$ in the case of patients who underwent different procedures; 10 -year OS was $60 \%$ and $6 \%$ respectively (Fig. 3 ).

Haemoptysis occurred in 6 men and 3 women and it was a poor prognostic factor. Median OS in these patients was 6 months vs. 44 months in patients who did not experience it. None of the patients who reported haemoptysis before diagnosis survived 5 years.

In single factor analysis, it was found that OS is affected by gender $(p=0.009)$, size of tumour $(p=0.02)$, type of resection ( $p=0.002)$, surgical radicalism $(p=0.047)$ and haemoptysis $(p=0.002)$. In the observation OS was not influenced by clinical stage according to TNM sarcoma classification ( $p=0.21$ ), clinical stage according to TNM lung cancer classification ( $p=0.42$ ), histological grade (G) $(p=0.48$ in 3-stage grading and $p=0.28$ in 2-stage grading), histological type of sarcoma, age $<50<(p=0.37)$, adjuvant therapy ( $p=0.71)$, and time between symptoms' appearance and surgical treatment $(p=0.86)$.

When different factors were present simultaneously, a variable impact was found for gender, haemoptysis, surgical radicalism and palliative therapy. Risk of death in men with PPS was almost 7 times higher than in women. Occurrence of haemoptysis increased risk of death almost 41 times. Non-radical treatment increased risk of death almost 80 times. Among patients who underwent palliative therapy the risk was 42 times higher (Table I).

\section{Progression-free survival (PFS)}

Median PFS was 65 months (5- and 10-year PFS was $53 \%$ and $32 \%$ respectively).

The PFS depended on gender $(p=0.04)$ and histological type in patients with PNET ( $p=0.008)$. In the case of gender, higher PFS was found in women. Median PFS in women

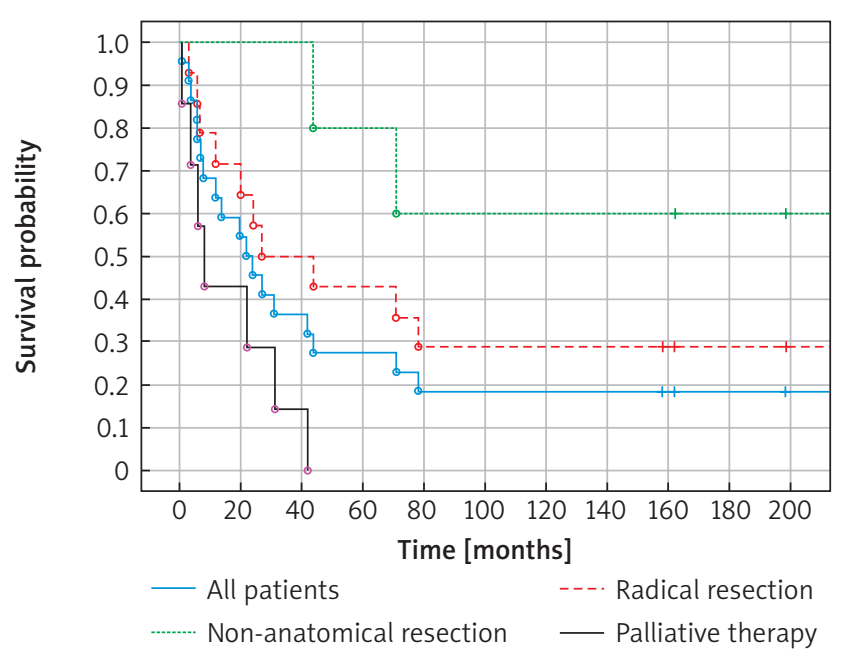

Fig. 3. Actuarial survival of all resected patients as a function of resection type

was 65 months, while in men it was 19 months $(p=0.04)$ (65 for entire group). Five- and 10-year PFS in women was $75 \%$ and $45 \%$ respectively. Progression of disease in men occurred within 5 years.

A correlation between type of sarcoma and progression of disease was found. Median PFS in patients with PNET type of sarcoma was 16 months, while for the rest of the group it was 65 months $(p=0.008)$. In all patients with such a diagnosis, progression occurred within 5 years. A local recurrence was noted in 1 case and in 2 cases distant metastases (to lung and bones) were identified.

\section{Discussion}

\section{Group}

The study included 22 patients diagnosed with PPS. The series of other authors are presented in Table II.

Table I. Association between predicted variables and overall survival using Cox's proportional hazards model

\begin{tabular}{lccc} 
Parameter & P-value & Hazard ratio (HR) & $95 \% \mathrm{Cl} \mathrm{HR}$ \\
Gender & 0.002 & 6.610 & $2.008-21.764$ \\
\hline $\mathrm{Kr}$ & 0.001 & 40.864 & $4.264-391.618$ \\
\hline Radicalism & 0.007 & 79.714 & $3.335-1905.510$ \\
\hline Palliative therapy & 0.023 & 42.035 & $1.666-1060.460$ \\
\hline
\end{tabular}

Table II. Groups involved in PPS treatment analysis

\begin{tabular}{lll} 
Author & Duration & Number of patients \\
\hline Mac Cormack and Martini & $1926-1989$ & 42 \\
\hline Nascimento et al. & $1950-1978$ & 18 \\
\hline Janssen et al. & $1959-1991$ & 22 \\
\hline Regnard et al. & $1973-1997$ & 24 \\
\hline Bacha et al. & $1981-1996$ & 23 \\
\hline Porte et al. & $1982-1998$ & 18 \\
\hline
\end{tabular}


This group comprised $0.098 \%$ of all procedures carried out in the clinic and $0.506 \%$ of all procedures performed due to lung tumour (22 363 performed including 4343 because of lung tumour). In Porte's research $1.1 \%$ of patients underwent operations due to PPS among all operations on lung tumours [7]. This value is higher than the one presented by Dail [3]. Like in other analyses after admitting patients to the study, cases in which the tumour infiltrated the lung parenchyma and thorax wall were noted. Following criteria of Regnard and Porte, lesions which the infiltrated thorax wall to a minimal degree in comparison with the lungs were considered as PPS [7, 12].

Median age was between 48 and 51 years and had no impact on treatment outcomes. Janssen's series included 3 patients under 18 years old, aged 5, 14 and 17 years [7-12].

Median OS was 22 months (5- and 10-year survival was $27 \%$ and $18 \%$ respectively). In Janssen's series OS was 24 months and 5 -year OS was 44\%. Probability of 5-year survival in Regnard's study was 42\%. In Bacha's analysis 5 -year OS was $69 \%$. Median OS of 18 patients from Lille was 48 months, and 5-year survival was $43 \%[11,12]$.

In the studied group, there were 10 (45\%) men and 12 (55\%) women. Patients were between 28 and 70 years old (median: 47.5 years). There was a similar gender ratio in Porte's series, while in other studies men made up the majority of patients. Women had better prognoses. Median OS in women was 42 months, while in men it was only 6 months ( $p=0.009$ ) (22 months in entire group). Five-year OS in women was $42 \%$ and in men $10 \%$ (27\% for entire group). No men survived 10 years, whereas 10-year survival in women was 33\%. In Regnard's study, gender had no influence on OS [7-12].

\section{Symptoms}

Similarly to the group studied, in other studies no typical clinical symptom(s) were determined. Haemoptysis had a statistically significant impact on survival (OS, $p=0.002$ ). None of the patients who observed this symptom survived 5 years. Regnard et al. [12] also noted haemoptysis in 8 (35\%) patients. In the studied group $23 \%$ of patients did not report any symptoms, whereas in Porte's study half of patients were asymptomatic and in Regnard's 4 (17\%) patients $[7,12]$. Time between initial symptoms and surgery in our study was between 0 and 14 months (median: 2.5 months) and did not affect treatment outcome $(p=0.86)$. Other studies do not comment on duration of symptoms before implementation of treatment.

\section{Tumour size}

According to the TNM sarcoma classification (by UICC and AJCC) tumour diameter of $5 \mathrm{~cm}$ is a determining factor in assessing STS stage of development [13]. In the present study, 13 (59\%) patients had a tumour larger than $5 \mathrm{~cm}$ in the largest dimension and this group of patients had worse prognoses. Median OS of these patients was shorter in comparison with patients diagnosed with tumours $\leq 5 \mathrm{~cm}$ $(14,44$ months respectively, $p=0.02)$. Five-year OS in pa- tients with smaller tumours was $50 \%$ vs. $15 \%$ in those with larger tumours; 10 -year OS was $38 \%$ vs. $8 \%$ respectively. Size of the tumour did not affect PFS. In patients with tumours larger than $5 \mathrm{~cm}$, PFS was 36 months vs. 65 months in patients with tumour $\leq 5 \mathrm{~cm}(p=0.44)$.

In studies by Bacha and Regnard, no difference between OS of patients with tumours smaller and larger than $5 \mathrm{~cm}$ was found [11, 12]. In a report by Mayo Clinic [9] tumour size was considered to have an impact on survival. In the majority of patients from Memorial Sloan Kettering Cancer Center [8] size (less than or greater $5 \mathrm{~cm}$ ) did not influence survival $(p=0.2)$. A statistically significant correlation with tumour size was presented by Janssen; in patients with tumours larger than $4 \mathrm{~cm}$, median OS was 23 months ( $p=0.0033$ ) [10].

\section{Preoperative diagnosis}

Determining diagnosis prior to treatment implementation is an important element of the therapeutic strategy in all lung tumours. In the case of soft-tissue sarcomas, pathological analysis based on small biopsies or cytological smear is difficult $[4,13,14]$. Malignant tumour was diagnosed in $4(18 \%)$ patients. In 2 of the patients that were operated on, cancer was identified. In postoperative examination in both cases synovial sarcoma (G3) was identified. In the 2 remaining cases with infiltration to bronchial wall causing its narrowing, chondrosarcoma and angiosarcoma were identified. Insertion of " $Y$ " stents into the carina of the trachea was carried out in these patients.

In the series presented by Regnard et al. a preoperative diagnosis of malignant tumour was made in 13 patients, with correct identification of sarcoma in 9 out of 13 patients $(37.5 \%, n=24)$. In 15 patients $(62.5 \%, n=24)$ sarcoma was not identified prior to surgery and all these patients were operated on because of lung tumour suspicion [12]. In a study by Bacha et al. preoperative diagnoses were determined in 7 patients $(30 \%, n=23)$. Diagnosis was wrong in 4 patients $(17 \%, n=23)$ [11]. Porte et al. reported diagnosis before the operation in 8 patients $(44 \%, n=18)$. Cytological analysis of sputum was not useful in the diagnostic process of PPS in patients of this series [7]. Janssen et al. reported 2 cases with lung sarcoma diagnosis based on bronchofibroscopy. In both cases leiomyosarcoma was identified and both diagnoses were false positive (squamous cell carcinoma). Mediastinoscopy was carried out because lung tumour was suspected; however, in none of 5 cases were metastases to mediastinal lymph nodes found. Janssen shares the opinion put forward by Porte et al. that diagnosis cannot be determined based on cytological analysis. Intraoperative diagnosis based on examination of cryostat sections is also difficult. In a study of Janssen et al., analysis of 11 such "examinations on demand" were carried out and 8 patients $(73 \%, n=11)$ were suspected with mesenchymal tumour, which was the leading indication for tumour resection. In one case, however, obtained results were false-negative [10]. McCormack nad Martini [8] also noted difficulties in determining the proper diagnosis based on ad hoc examination of biopsies or their 
small volume. The lack of identification of cancer type in intraoperative examination in the studied group led to an increasing number of non-anatomical resections.

\section{Treatment}

\section{Surgical treatment}

In PPS the treatment of choice is anatomical resection of lung tissue with a tumour-free margin $[1,4,13]$. Such treatment was carried out in 14 analysed patients (63.6\%, $n=22$ ). Six patients were treated with non-anatomical resection. These tumours were peripherally located, the size of the tumours was 1-19 cm, and in one case the tumour infiltrated the mediastinum. Median OS in patients with $R_{0}$ resection was 27 months, while in patients treated with $\mathrm{R} 1-2$ resection it was 8 months $(p=0.047)$. Five- and 10 -year OS of patients who underwent radical treatment was $43 \%$ and $29 \%$ respectively. None of the patients who did not undergo $R_{0}$ resection survived 5 years. Patients who underwent non-anatomical resection had better prognosis. Median OS in these patients was 213 months, while for the rest of the patients it was 14 months ( $p=$ 0.002). Five-year OS of patients treated with not anatomical resections was $80 \%$ in comparison with $12 \%$ in the case of patients who underwent other types of surgery. Ten-year OS was $60 \%$ and $6 \%$ respectively. Median PFS of patients who underwent radical treatment was 65 months in comparison with 35 months in those who could not undergo such treatment. Similarly, in a group of patients who received non-anatomical resection, PFS was 65 months vs. 35 months in patients treated with anatomical resection $(p=0.47)$

The authors of other studies showed that the percentage of patients who underwent surgical treatment was 69-100\% depending on specific criteria. Complete resection could be carried out in 50-94\%. Extent of surgery depended on the local extent of the tumour. Resections were expanded to the thorax wall, diaphragm, atrium, superior vena cava and carina of trachea. Bacha used extracorporeal circulation, and in one case, for the purpose of reconstruction of the pulmonary artery, he used a homograft. According to Porte, non-anatomical resection (wedge or segmental) in small peripherally located tumours seems to increase the chance of renewal [7-12]. Our observations based on the studied group, in which after non-anatomical resections $3(66 \%, n=5)$ local recurrences occurred, confirm that view.

The PPS rarely spread through lymphatic vessels [8]. However, Regnard et al. observed N2 development in 2 out of 20 patients who underwent surgical treatment and N1 development in another 3 [11], which sums up to $22 \%$ of patients. Porte et al. noted 1 patient with lymph node metastasis of pulmonary cavities (N1) [7]. In Spraker's analysis, infiltration of lymph nodes was observed in $16 \%$ of 365 patients [15]. According to these reports, mediastinoscopy and lymphadenectomy of the mediastinum seem to be indicated, similarly to the treatment of lung cancer.

\section{Inductive and neoadjuvant therapy}

Infiltration of the right pulmonary artery and left atrium, as well as a large mass of tumour taking up the entire thoracic cavity in one of his patients, convinced Porte to implement inductive chemotherapy. Two patients received six cycles of inductive chemotherapy based on ifosfamide, doxorubicin and dacarbazine, which reduced the tumour by $50 \%$. Then patients received $R_{0}$ pneumonectomy and survived 20 and 58 months without recurrence showing signs of renewal. There was no other report of inductive chemotherapy used in treatment for PPS [7]. Previously, Wu et al. described administration of preoperative chemotherapy in a patient with haemangiopericytoma with high risk for resection [16].

\section{Adjuvant therapy}

In the studied group adjuvant therapy was used in $5(23 \%)$ patients and had no impact on OS $(p=0.71)$ or PFS $(p=0.13)$. In the Mac Cormack and Martini study [8] no impact of radiotherapy on patients survival was observed. Multidrug schemata of chemotherapy used in non-radical treatment after resection were described by Janssen et al. [10]. This therapy rarely had an influence on survival. Janssen observed that adjuvant therapy did not improve survival; all 4 patients who received this treatment died within 23 months after surgery.

\section{Pathomorphological analysis}

Histological types of PPS were identified according to the $3^{\text {rd }}$ edition of the WHO sarcoma classification [17]. Ten types of sarcoma were identified. In the Bacha and Porte et al. report, malignant fibrous histiocytoma (MFH) was the most common type of PPS in the studied group. Regnard et al. reported that fibrosarcoma was the most common type, diagnosed in 10 (41\%) patients. Leiomyosarcoma was most frequently reported in older studies, whereas in our study it was diagnosed in only 3 patients [8]. Some published results of studies [7-12] did not indicate any impact of histological type of sarcoma on survival. Bacha noted that patients with MFH had better prognosis. We could not confirm such a correlation in our research (OS, $p=0.65)$. Diagnosis of MFH also had no impact on PFS $(p=0.23)$. PNET was identified in 3 (13.6\%) patients. Diagnosis of this type of sarcoma did not statistically influence OS $(p=0.98)$ but had a negative impact on PFS ( $p=0.008)$. In each patient diagnosed with PNET, progression of disease was observed (median: 16 vs. 65 months in PNET and other types of sarcoma, respectively). In one case local recurrence was noted and in 2 cases distant metastases to bones and the other lung. Because of the small number of cases and difficulties in creating subgroups (this disease occurs very rarely), it is crucial to be careful in drawing definitive conclusions.

\section{Histological malignancy}

Overall survival of patients described by Janssen et al. was statistically higher in patients with PPS with a low degree of malignancy. None of the patients with G1 malig- 
Table III. Results and prognostic factors of lung resection for primary pulmonary sarcoma

\begin{tabular}{lcccccc} 
Authors & Period & $\begin{array}{c}\text { Patients } \\
n\end{array}$ & $\begin{array}{c}\text { Operated } \\
\text { patients } \\
n(\%)\end{array}$ & $\begin{array}{c}\text { Complete } \\
\text { resection } \\
n(\%)\end{array}$ & $\begin{array}{c}\text { Overall survival (OS) } \\
\text { Resection } R_{0} \\
(\%)\end{array}$ & Prognostic factors \\
\hline MacCormack, Martini [8] & $1926-1989$ & 42 & $29(69)$ & $29(69)$ & Size $<5 \mathrm{~cm}(p=0.2)$ \\
\hline Nascimento et al. [9] & $1950-1978$ & 18 & $17(94)$ & $17(94)$ & Size $<3 \mathrm{~cm}$ \\
\hline Janssen et al. [10] & $1959-1991$ & 22 & $18(82)$ & $11(50)$ & 44 & $\mathrm{R}_{0}$, size $<4 \mathrm{~cm}$, grade \\
\hline Regnard et al. [11] & $1973-1997$ & 24 & $23(96)$ & $20(83)$ & 48 & Stage lung carcinoma \\
\hline Bacha et al. [12] & $1981-1996$ & 23 & $20(87)$ & $14(61)$ & 69 & $\mathrm{R}_{0}$ \\
\hline Porte et al. [7] & $1982-1998$ & 18 & $18(100)$ & $16(89)$ & 43 & $\mathrm{R}_{0}$, stage lung carcinoma \\
\hline Current series & $1994-2009$ & 22 & $20(91)$ & $14(64)$ & $48 / 80^{*}$ & $\mathrm{R}_{0}$, size $<5 \mathrm{~cm}$, gender \\
\hline
\end{tabular}

${ }^{\star}$ Non-anatomical resection.

nancy died of this cause. Median survival of patients with G2 malignancy was 60 months, whereas in patients with G3 malignancy according to the FNCLCC median survival was 17 months $(p=0.040)$. Unlike in the analysed series [10], we did not observe such a correlation. Median OS of patients with G1 malignancy was 42 vs. 20 months in patients with G3 malignancy, and 5-year survival was $43 \%$ vs. $9 \%$ respectively $(p=0.48)$. Analysis of the G1 group was compared with $\mathrm{G} 2+\mathrm{G} 3$ groups $(p=0.28)$.

\section{STS stage of development}

According to the $3^{\text {rd }}$ edition of the TNM sarcoma classification developed by the Union for International Cancer Control (UICC) and the American Joint Committee on Cancer (AJCC) published by the WHO in 2002, most patients were classified in stage III. This group contained nearly half patients with tumours larger than $5 \mathrm{~cm}(45 \%, n=22)$ and sarcomas with a high degree of malignancy ( $G 2$ and $G 3$ on a 3-stage scale). Patients with stages IA and IB had a better prognosis than those with stages IIA and III, but it was statistically insignificant $(p=0.21)$. However, median OS in the first group was twice as high -42 months vs. 14 months in the third one.

\section{TNM of lung cancer}

Porte and Regnard et al. [7, 11] adopted the classification of lung tumours to PPS. According to the Regnard et al. study, probability of 5 -year OS in stage IB was $83 \%$ while in stage IIB none of the patients survived 5 years, whereas the probability of 3-year OS was 30\% $(p<0.05)$ and was similar to the one reported by Porte $(p<0.05)$. In our analysis, we did not observe any correlation between OS, PFS or stage of development according to lung tumour classification applied to PPS.

The differences between OS and PFS estimated by Kaplan-Meier curves did not confirm TNM prognostic value for OS $(p=0.42)$ or PFS $(p=0.77)$ in our study.

\section{Prognostic factors}

Surgical treatment, especially $\mathrm{R}_{0}$ resection, is the most efficient method of PPS treatment. Complete resec- tion of primary sarcoma significantly improves prognosis. Further analysis of resections with a tumour-free margin in the studied group showed that survival was better in patients who underwent non-anatomical resections. Patients with tumours larger than $5 \mathrm{~cm}$ have worse prognosis. Looking for a correlation between size of tumour and survival, Nascimento et al. [9] stated that size under $3 \mathrm{~cm}$ is a good prognostic factor, while Janssen et al. suggested $4 \mathrm{~cm}$. According to Bacha et al. [12] patients with MFH had a better prognosis. Janssen et al. [10] considered that degree of histological malignancy is a prognostic factor. In our study we did not reach such a conclusion, and nor did Porte, Regnard and Bacha [7, 11, 12]. Porte and Regnard et al. $[7,11]$ suggested that stage of development based on TNM lung cancer (adopted to PPS) is one of the prognostic factors. Worse prognoses were noted in men. Haemoptysis was a bad prognostic factor (Table III).

\section{Conclusions}

Because of the small group of cases analysed by various authors and in our research, statistical analysis is strongly limited. Studies including larger groups of patients diagnosed with PPS are necessary.

\section{Disclosure}

The authors report no conflict of interest.

\section{References}

1. Shields TW, Robinson PC. Uncommon primary malignant tumors of the lung. In: General Thoracic surgery. Shields TW. $5^{\text {th }}$ ed. LW \& W, 2000.

2. Dail DH. Uncommon tumors, sarcomas. In: Pulmonary Pathology: Tumors. Dail DH, Hammar SP, Colby TV (eds.). Springer, New York 1995; 265-293.

3. Suster S. Primary sarcomas of the lung. Semin Diagn Pathol 1995; 12: 140-157.

4. Miettinen M. Modern Soft Tissue Pathology, Tumors and NonNeoplastic Conditions. University Press, Cambridge 2010.

5. Martini N, Hajdu SI, Beattie EJ. Primary sarcoma of the lung. I Thorac Cardiovasc Surg 1971; 61: 33-38.

6. Guccion JG, Rosen SH. Bronchopulmonary leiomyosarcoma and fibrosarcoma: a study of 32 cases and review of the literature. Cancer 1972; 30: 836-847.

7. Porte HI, Metois DG, Leroy X, Conti M, Gosselin B, Wurtz A. Surgical treatment of primary sarcoma of the lung. Eur J Cardiothorac Surg 2000; 18: 136-142. 
8. McCormack PM, Martini M. Primary sarcomas and lymphomas of the lung In: Thoracic Surgery: Frontiers and Uncommon Neoplasms. Martini N, VogtMoykopf I. CV Mosby, St. Louis 1989; 261-283.

9. Nascimento AG, Unni KK, Bernatz PE. Sarcomas of the lung. Mayo Clin Proc 1982; 57: 355-359.

10. Janssen JP, Mulder JJS, Wagenaar SS, Elbers HRJ, Van Den Bosch JMM. Primary sarcoma of the lung: a clinical study with long term follow-up. Ann Thorac Surg 1994; 58: 1151-1155.

11. Regnard JF, Icard P, Guibert L, Thomas de Montpreville V, Magdalenat P, Levasseur P. Prognostic factors and results after surgical treatment of primary sarcomas of the lung. Ann Thorac Surg 1999; 68: 227-231.

12. Bacha EA, Wright CD, Grillo HC, Wain JC, Moncure A, Keel SB, Donahue DM, Mathisen DJ. Surgical treatment of pulmonary sarcomas. Eur J Cardiothorac Surg 1999; 15: 456-460.

13. Fletcher CD, Hogendoorn P, Mertens F, Bridge J. WHO Classification of Tumours of Soft Tissue and Bone. $4^{\text {th }}$ ed. IARC Press, Lyon 2013; 9-18.
14. Bhattacharya D, Datta S, Das A, Halder KC, Chattopadhyay S. Primary pulmonary synovial sarcoma: a case report and review of literature. Int J Appl Basic Med Res 2016; 6: 63-65.

15. Spraker MB, Bair E, Bair R, Connell PP, Mahmood U, Koshy M. An analysis of patient characteristics and clinical outcomes in primary pulmonary sarcoma. J Thorac Oncol 2013; 8: 147-151.

16. Wu YC, Wang LS, Chen W, Fahn HJ, Huang MH, Whang-Peng J. Primary pulmonary malignant hemangiopericytoma associated with coagulopathy. Ann Thorac Surg 1997; 64: 841-843.

17. Fletcher CDM, Rydholm A, Singer S, Sundaram M, Coindre JM. Soft tissue tumours: epidemiology, clinical features, histopathological typing and grading. In: World Health Organization Classification of Tumours, Pathology and Genetics of Tumours of Soft Tissue and Bone. Fletcher CDM, Unni KK, Mertens F. IARCPress, Lyon 2002; 9-18. 